\title{
IDENTIFIKASI EKSTRAKSI FITUR UNTUK GERAKAN TANGAN DALAM BAHASA ISYARAT (SIBI) MENGGUNAKAN SENSOR MYO ARMBAND
}

\author{
Angga Rahagiyanto \\ Program Studi Rekam Medik, Jurusan Kesehatan, Politeknik Negeri Jember \\ Jl. Mastrip, Jember, Jawa Timur \\ Email : rahagiyanto@polije.ac.id
}

\begin{abstract}
ABSTRAK
Pemodelan gerakan tangan manusia untuk mengenali Bahasa isyarat SIBI telah banyak diamati oleh peneliti dengan menggunakan pendekatan jenis kamera dan sensor yang berbeda-beda. Tujuan akhirnya adalah agar dihasilkan proses pengenalan gerakan isyarat yang kuat, cepat dan akurat. Salah satu pendekatan yang mampu menangkap gerakan tangan secara penuh adalah dengan menggunakan sensor pada alat MYO Armband. Makalah ini menjelaskan tentang bagaimana cara mengidentifikasi data mentah yang dihasilkan dari sensor MYO Armband dan mengekstraksi fiturnya agar dapat digunakan untuk mengenali gerakan tangan, lengan dan kombinasi keduanya pada kamus Bahasa isyarat SIBI. MYO Armband menggunakan lima sensor: accelerometer, gyroscope, orientation, orientation-euler dan EMG. Setiap sensor menghasilkan data yang berbeda dalam skala dan ukuran. Hal ini membutuhkan proses untuk membuat data menjadi seragam. Penelitian ini menggunakan metode min-max untuk menormalisasi setiap data pada sensor MYO Armband dan metode Moment Invariant untuk mengekstrak fitur vector gerakan tangan. Pengujian dilakukan menggunakan Bahasa isyarat gerakan isyarat statis maupun dinamis. Pengujian dilakukan dengan menggunakan cross validation dihasilkan bahwa perbedaan dalam gerakan isyarat statis maupun dinamis dapat ditentukan dengan baik.
\end{abstract}

Kata Kunci: isyarat tangan, bahasa isyarat, sensor Myo Armband, Ekstraksi fitur, metode Moment Invariant

\begin{abstract}
Indonesian: Indonesian SIBI has been widely reviewed by researchers using different types of cameras and sensors. The ultimate goal is to produce a strong, fast and accurate movement recognition process. One that supports talk of movement using sensors on the MYO Armband tool. This paper explains how to use raw data generated from the MYO Armband sensor and extract integration so that it can be used to facilitate complete hand, arm and combination movements in the SIBI sign language dictionary. MYO armband uses five sensors: accelerometer, gyroscope, orientation, euler-orientation and EMG. Each sensor produces data that is different in scale and size. This requires a process to make the data uniform. This study uses the min-max method to normalize any data on the MYO Armband sensor and the Moment Invariant method to extract the vector features of hand movements. Testing is done using sign language Movement statistics both dynamic signals. Testing is done using cross validation.
\end{abstract}

Keyword: hand gesture, sign language, MYO Armband sensor, feature extraction, Moment Invariant Method

\section{PENDAHULUAN}

Kemajuan teknologi HCI membuat teknologi menjadi persyaratan penting. Salah satu implementasi HCI adalah pengenalan isyarat tangan. Sekarang penelitian tentang pengenalan isyarat tangan telah dilakukan di berbagai bidang seperti realitas virtual, robot, game komputer (animasi), kendali jarak jauh, pengenalan bahasa isyarat dan banyak lagi.
Perkembangan teknologi ini semakin memungkinkan orang untuk berinteraksi, komunikasi yang baik antara manusia dan mesin [1] serta komunikasi untuk orang normal dengan orang cacat. Banyak penelitian menggunakan pengenalan isyarat bahasa isyarat untuk membantu komunikasi mereka [2].

Gesture adalah simbol yang 
diekspresikan melalui gerakan fisik dan ekspresi emosional sebagai bentuk komunikasi bahasa tubuh, melibatkan gerakan yang alami dan intuitif daripada jari, tangan, lengan, kepala, wajah. Ini memiliki makna khusus dengan maksud untuk mendorong dialog antara orangorang dalam menyampaikan informasi atau untuk berinteraksi dengan lingkungan [3]. Dapat disimpulkan bahwa gerakan tangan adalah komunikasi bahasa tubuh yang dibentuk oleh posisi lengan dan jari.

Ada dua jenis gerakan tangan dalam bahasa isyarat; pergerakan statis dan dinamis. Gerakan statis adalah gerakan tangan yang mengacu pada bentuk tangan dan jari-jari diam dalam waktu tertentu seperti bahasa isyarat untuk angka-angka tersebut. Kunci gerakan statis adalah pola atau bentuk tangan dan jari. Gerakan dinamis adalah kombinasi seri dari semua jenis gerakan yang membentuk pola gerakan seperti bahasa isyarat untuk kata [4]. Kunci gerakan dinamis adalah gerakan pola tangan berubah setiap saat. Bahasa isyarat memiliki kombinasi gerakan statis dan dinamis.

Pemodelan postur tangan manusia baik gerakan gerak statis maupun dinamis dalam beberapa tahun terakhir telah menarik perhatian banyak peneliti untuk mengembangkan $\mathrm{HCI}$ bahasa isyarat. Berbagai macam pendekatan baik untuk gerakan gerakan statis maupun dinamis dan alat yang digunakan oleh banyak peneliti untuk menemukan model yang tepat untuk dapat mengenali gerakan statis atau dinamis dengan cepat dan akurat. Pemodelan menggunakan banyak pendekatan seperti pendekatan pemodelan statistik [5], [6] visi komputer [7], [8] dan pengenalan pola [9], [10] pemrosesan gambar [11] - [13]. Setiap pemodelan memiliki kelebihan dan kekurangan.

Verma [14] menggambarkan ulasan berbagai teknik pengenalan gerakan sebagai berikut:

1. Pengenalan gerakan menggunakan sarung tangan yang memiliki sensor accelerometer. Model ini mendeteksi pose sudut tangan dan sensor RGB untuk mendeteksi warna kulit.

2. Pengenalan gerakan menggunakan Hidden Markov Models dan webcam sebagai alat untuk mendapatkan gambar gerakan tangan.
3. Pengenalan gerakan menggunakan webcam sebagai alat untuk mendapatkan gambar gerakan tangan. Model ini bertujuan untuk menyediakan sistem real-time menggunakan parameter bentuk sehingga menghasilkan tingkat pengakuan tinggi dengan waktu komputasi minimum. Kelemahan dari metode ini adalah untuk menentukan parameter tanpa pendekatan gerakan yang sistematis dan parameter maksimum dalam pendekatan ini didasarkan pada asumsi.

4. Pengenalan gerakan menggunakan kamera heterogen. Model ini menggunakan langkah kalibrasi ganda dengan dua kamera, yaitu webcam dan kamera termal. Webcam untuk menangkap pergerakan bahasa isyarat. Kamera termal untuk segmentasi tubuh dan berurusan dengan latar belakang yang kompleks dan variasi pencahayaan yang disebabkan oleh proyektor. Kelemahan dari metode ini adalah waktu komputasi yang lama, sejumlah gerakan yang dapat dilakukan dengan satu tangan.

Makalah ini menjelaskan pendekatan baru untuk mengidentifikasi dan menganalisis ekstraksi fitur statis dan dinamis menggunakan sensor MYO Armband. Armband MYO memiliki lima sensor; akselerometer, giroskop, orientasi, orientasi-Euler dan EMG. Setiap sensor memiliki skala dan ukuran data yang berbeda. Penelitian ini menggunakan metode Moment Invariant untuk ekstraksi fitur. Hasil ekstraksi fitur ini dianalisis untuk menentukan kinerja fitur untuk mengenali gerakan tangan sesuai dengan standar bahasa isyarat.

MYO adalah alat dalam bentuk ban lengan yang dibangun oleh Thalmic Labs. MYO mengidentifikasi gerakan perpindahan otot lengan. MYO memiliki 8 pod sensor EMG (elektromiografi) untuk impuls listrik dari setiap gerakan tangan, dan unit pengukuran inersia (IMU) 9-sumbu untuk mendeteksi arah gerakan lengan.

M. Sathiyanarayanan [15] meneliti penggunaan MYO Ambrand untuk mengontrol navigasi di Apple Maps. Penelitian ini diukur secara statistik menggunakan model SUS. Fokus kuesioner pada sisi ergonomis terkait dengan 
penggunaan alat, seperti respon publik, bagaimana dan kemudahan penggunaan peralatan, tingkat kenyamanan dan stres, untuk menemukan karakteristik navigasi gerak menggunakan MYO. Hasil dari penelitian ini adalah MYO dapat digunakan untuk mendukung pembuatan peta navigasi interaktif dengan gerakan tangan [15].

T. mulling [16] mempelajari isyarat karakteristik aspek ergonomis, kognitif dan potensi sosial untuk berkontribusi pada desain gerakan tangan dalam folder aplikasi navigasi. Tes menggunakan observasi dan kuesioner. Hasil penelitian menunjukkan bahwa desain dan bentuk gesture prototipe MYO dapat dikembangkan lebih lanjut [16].

A. F. Ruiz-olay [17] memprediksi intens gerakan menggunakan pengenalan pola ke sensor EMG sinyal biologis. Penelitian ini membandingkan dua studi algoritma pengenalan gestur berbasis EMG yang dimaksudkan untuk gesture. Algoritma yang menggunakan informasi yang dihasilkan data kinetik dan EMG lebih baik untuk klasifikasi 5 gerakan tangan daripada hanya menggunakan data EMG [17].

M. Sathiyanarayanan [18] menunjukkan penggunaan gelang MYO untuk perawatan fisioterapi. Studi ini menganalisis diagnostik EMG MYO untuk mendeteksi kelainan pada gerakan tangan. Tes dilakukan pada 24 mahasiswa kedokteran menggunakan kuesioner SUS. Penelitian ini dapat menjadi cara alternatif untuk mendukung analisis fisioterapi interaktif, membantu pemahaman yang lebih baik tentang sistem keseluruhan miokardium dan membantu dokter mendiagnosis lebih awal [18].

$\mathrm{Z}$ Arief. [19] membandingkan fitur ekstraksi 5 sinyal EMG 8 pod menggunakan ban MYO. Metode fitur ekstraksi yang dilakukan adalah Mean Absolute Value (MAV), Variance (VAR), Willison Amplitude (WAMP), Panjang Gelombang (WL), dan Zero Crossing (ZC). Penelitian ini menghasilkan rekomendasi untuk proses ekstraksi fitur menggunakan MAV dan WL [19].

\section{METODOLOGI}

Makalah ini menunjukkan sifat dari sensor yang ada pada gelang MYO dan cara mengekstraksi fitur untuk proses pengenalan gerakan tangan. Pertama, kami mengambil data dari semua sensor MYO Ambrand. Kedua, kami mengamati data sensor dan mengubah data menjadi vektor fitur menggunakan metode invarian Moment. Ketiga, kami mengamati vektor fitur sebagai dasar pengenalan gerakan tangan.

\section{A. Sensor MYO Armband}

Ada 4 jenis sensor perangkat keras tertanam di MYO armband; EMG, akselerometer, giroskop, dan magnetometer. MYO menggunakan Inertial Measurement Unit (IMU) untuk mendeteksi rotasi dan translasi. IMU digunakan untuk mengukur akselerasi dan kecepatan sudut pada 3-sumbu yang merupakan bagian penting dari sistem kontrol navigasi. Ada berbagai teknik yang dilakukan untuk menghasilkan IMU, salah satunya adalah menggabungkan sensor accelerometer dan gyrometer [20]. Dengan demikian, gelang MYO menggunakan lima jenis sensor untuk membantu mengidentifikasi gerakan yang dilakukan, terdiri dari: EMG, akselerometer, giroskop, orientasi, dan orientasi-euler. Penelitian ini menggunakan lima jenis sensor tersebut untuk mengidentifikasi dan menganalisis ekstraksi fitur dari gerakan statis dan dinamis.

1) Sensor EMG: Gelang MYO adalah gelang. MYO menggunakan 8 blok, yang masing-masing blok berisi elektroda / pod Elektromyography (EMG) berfungsi untuk membaca aktivitas gerak otot ekstensor digitorum dan fleksor digitorum seperti yang ditunjukkan pada gambar 1 .

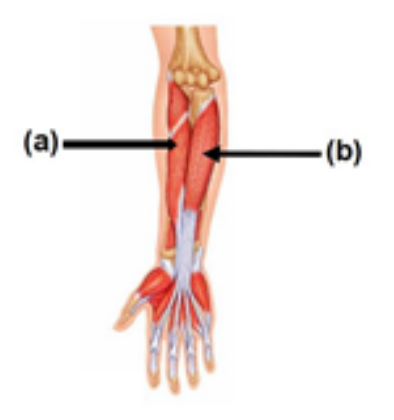

Gambar 1. Ekstensor digitorum (a) \& fleksor digitorum (b)

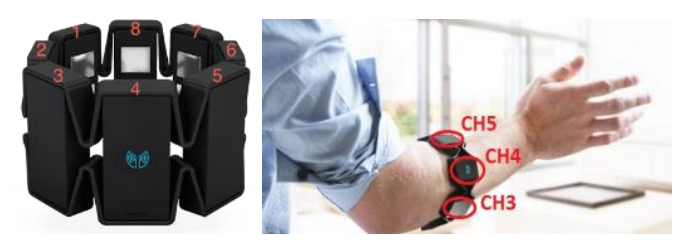

Gambar 2. Pod/ Elektrode sinyal EMG 
Gambar 2 menunjukkan konfigurasi elektroda pada ban MYO dan bagaimana menggunakan alat ini. Ada tiga saluran yang menarik untuk diamati: Saluran $4(\mathrm{CH} 4)$ adalah memiliki logo biru yang dipasang di posisi lengan bawah, diikuti oleh saluran 5 (CH5) dengan lawan searah jarum jam dan saluran 3 (CH3) searah jarum jam.

2) Sensor Accelerometer: Sensor accelerometer dan sensor giroskop untuk memberikan informasi tentang percepatan dalam tiga arah, dan rotasi di setiap sumbu $x, y$ dan $z$.
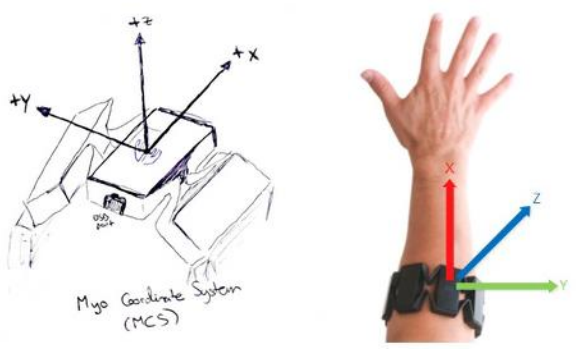

Gambar 3. Sumbu x, y, dan z pada sensor accelerometer dan gyroscope

Gambar 3 menunjukkan bahwa sensor accelerometer memiliki arah x, y, dan z. Sensor accelerometer digunakan untuk mengukur akselerasi, perpindahan, getaran, dan percepatan gravitasi. Accelerometer juga berfungsi untuk mengukur akselerasi dinamis dan statis. Akselerasi dinamis adalah ukuran akselerasi objek bergerak, dan akselerasi statis adalah pengukuran gravitasi.

3) Sensor Gyroscope: Sensor giroskop digunakan untuk mengukur orientasi hukum kekekalan momentum sudut. Di bawah arah sumbu menurut Gambar 3, giroskop telah menghasilkan kecepatan sudut arah tiga sumbu, yaitu: sumbu $\mathrm{x}$ bernama sudut psi (depan dan belakang), sumbu y disebut sudut phi (kanan dan kiri). ), dan sumbu $\mathrm{z}$ disebut sudut theta (atas dan bawah).

4) Sensor Orientation: Sensor orientasi pada gelang MYO menentukan sudut gerakan dengan menghitung arah medan magnet Bumi (magnetometer) dan gravitasi (akselerometer) [21].

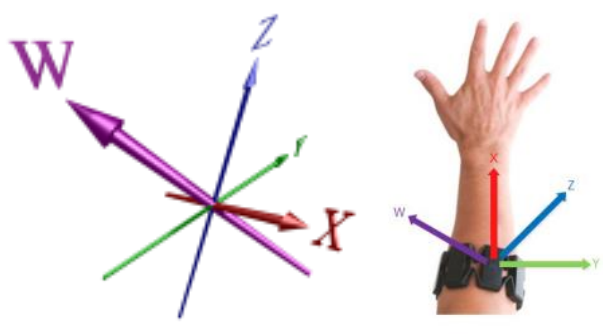

Gambar 4. Sumbu x, y, z dan w pada sensor orientation

Dalam dunia 4D, ada arah sumbu lain yang tegak lurus terhadap sumbu $\mathrm{x}, \mathrm{y}$, dan $\mathrm{z}$ yang ditunjukkan oleh label w, atau dinamkan dengan sumbu keempat. Sumbu baru ini juga memiliki arah positif dan negatif, yang disebut sebagai + w dan -w. $X, y, z$ dan w digunakan bersama untuk mengukur orientasi gerakan yang dilakukan. Sumbu W adalah arah sumbu tegak lurus terhadap sumbu $\mathrm{x}, \mathrm{y}$ dan $\mathrm{z}$ seperti yang ditunjukkan pada gambar 4. Fungsi pada MYO armband adalah untuk menentukan arah posisi gerakan tangan yang telah dilakukan.

5) Sensor Euler-Orientation: Sensor Euler-Orientation adalah sensor yang dikembangkan dari sensor orientasi. Sensor ini menjelaskan kombinasi gerakan translasi dan rotasi (dinamis) untuk menghitung nilai $\mathrm{x}, \mathrm{y}, \mathrm{z}$ dan $w$ dalam orientasi angka menggunakan perhitungan [22] untuk mendapatkan euler 3sumbu yaitu roll, pitch, dan yaw seperti yang ditunjukkan pada gambar 5 .
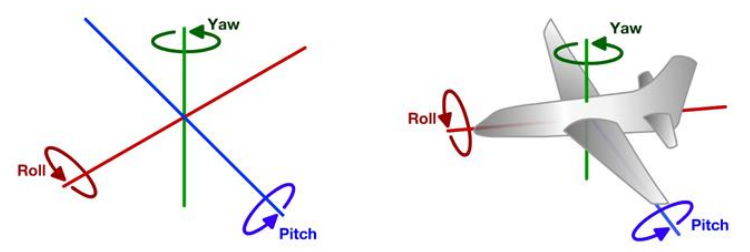

Gambar 5. Sumbu roll, pitch, and yaw pada sensor euler-orientation.

\section{B. Hand Gesture for Sign Language}

Eksperimen ini menggunakan beberapa gerakan tangan sesuai dengan gerakan statis dan dinamis. Setiap gerakan mendapat perlakuan berbeda. Tujuannya adalah untuk mengetahui pola, pengaruh gerakan terhadap sensor yang ada pada alat MYO armband dan ekstraksi fitur. 
1) Gerakan Statis untuk Karakter Abjad A-F

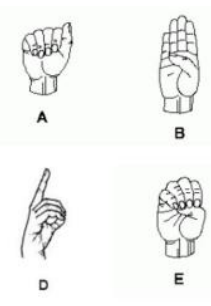

(a)

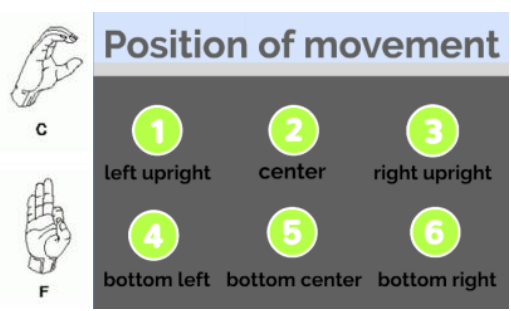

(b)
Gambar 6. Gerakan Tangan untuk abjad A-F (a) \& posisi arah pergerakan tangan (b)

Setiap gerakan dalam gambar 6 (a) dilakukan 6 kali dengan 6 posisi arah gerakan seperti pada Gambar 6 (b). Posisi tangan adalah kiri atas (1), tengah tegak (2), kanan tegak (3), kiri bawah (4), tengah bawah (5), dan kanan bottom (6). Posisi tangan yang dihasilkan dari pengamatan para peneliti melakukan gerakan dalam kehidupan sehari-hari.

\section{2) Gerakan Dinamis}

Gerakan dinamis adalah gerakan kanan dan kiri, atas dan bawah, dan maju mundur. Gerakan ini digunakan untuk mengukur kecepatan, arah, dan posisi yang terkandung dalam Myo Armband seperti yang ditunjukkan pada gambar 7 .
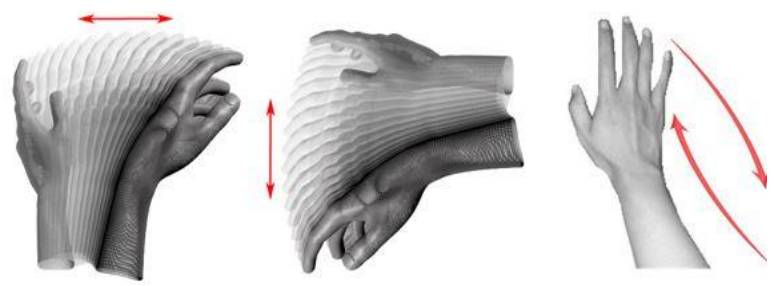

Gambar 7. Gerakan dinamis pada gesture tangan.

C. Percobaan-Percobaan.

Eksperimen dilakukan untuk memahami karakteristik fitur sensor MYO.

1) Gerakan tangan yang berbeda untuk memposisikan arah gerakan yang berbeda: Percobaan ini mengacu pada gerakan dinamis, yaitu gerakan kanan dan kiri, atas dan bawah, dan bolak-balik yang secara otomatis akan memberikan posisi berbeda arah pergerakan antara gerakan satu sama lain.

2) Gerakan tangan berbeda dari posisi arah gerakan yang sama: Eksperimen ini mengacu pada gerakan statis, para peneliti mengambil beberapa contoh gerakan statis pada SIBI yang menggerakkan alfabet AF (6 gerakan) dengan posisi gerakan yang sama, paralel (tegak lurus) ke bahu.

3) Gerakan tangan yang sama dengan posisi arah gerakan berbeda: Percobaan ini mengacu pada gerakan statis, dengan gerakan yang sama, tetapi gerakan menuju posisi yang berbeda. Peneliti telah menentukan bahwa gesture yang dilakukan adalah gesture alphabet A.

D. Metode yang Diusulkan

Hasil pengukuran masing-masing gerakan tangan menunjukkan beberapa masalah berupa data sensor non uniformities baik dalam skala maupun ukuran. Ketika data ini digunakan langsung untuk proses pengenalan, akan ada banyak kesalahan dalam pendahuluan karena datanya tidak seragam. Ada juga kesalahan yang disebabkan oleh gerakan ambigu, kegagalan sensor, pengukuran durasi pendek, atau membuat kesalahan pengukuran waktu awal [23].

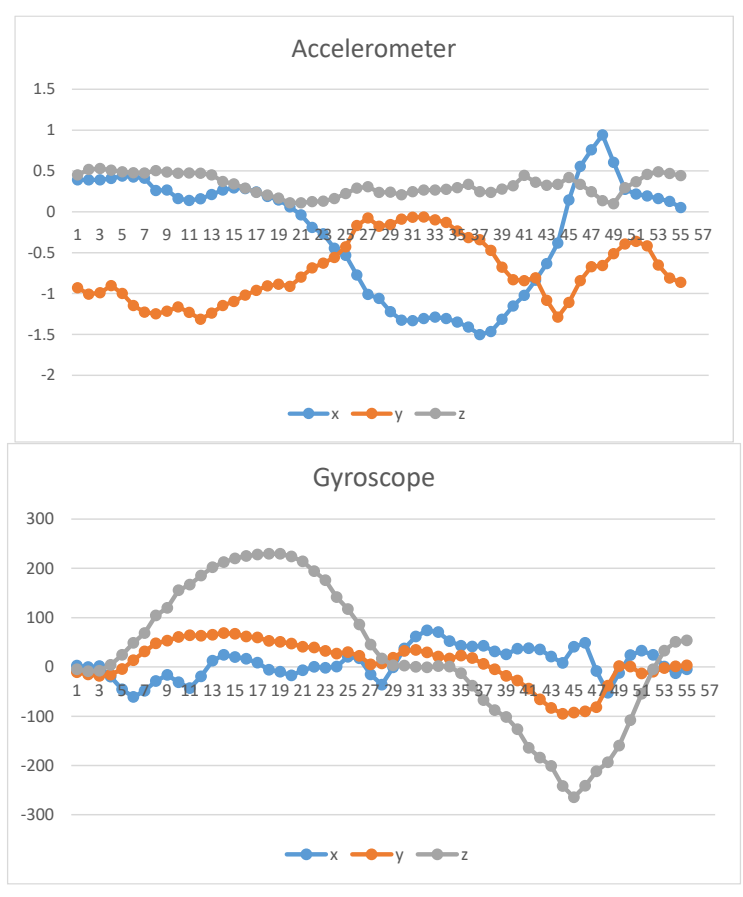

Gambar 8. Gambar Dari Sensor Accelerometer Dan Gyroscope 


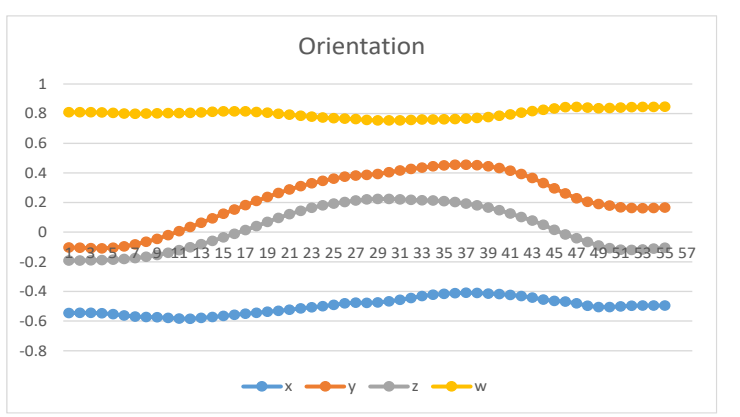

Orientation-Euler

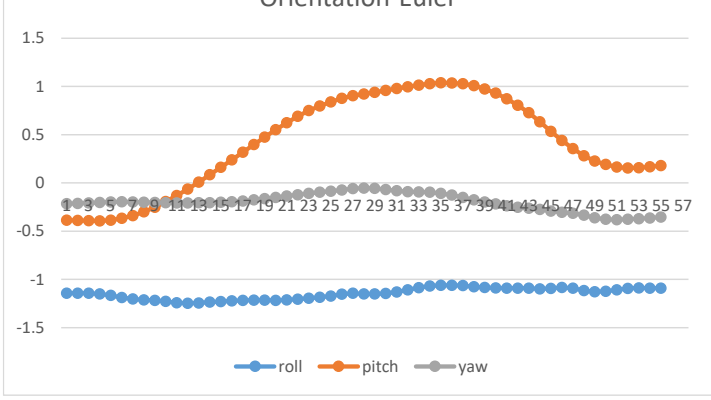

Gambar 9. Gambar Orientation Dan Orientation-Euler

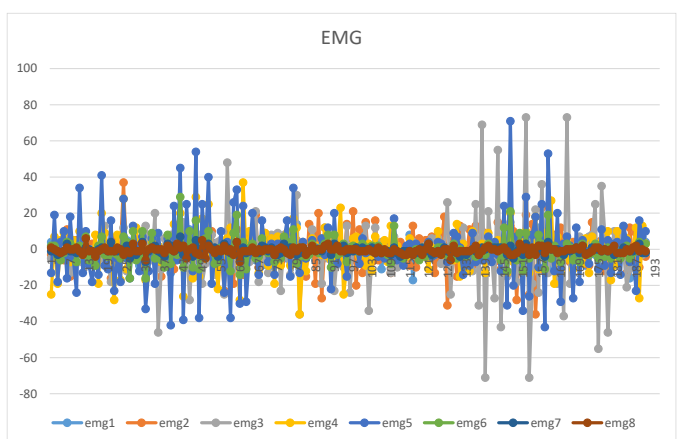

Gambar 10. Data Diri Sensor EMG

Gambar 8 dan 9 menunjukkan bahwa data yang diukur membentuk pola dengan koordinat 4 sumbu $(\mathrm{x}=$ biru, oranye $=\mathrm{y}, \mathrm{z}=$ abu-abu, $\mathrm{w}=$ kuning) dari masing-masing sensor dan arah gerakan. Ada beberapa garis yang memotong titik nol. Gambar 10 menunjukkan pola grafik kontraksi otot yang diperoleh dari sensor EMG. Data ini adalah data mentah yang memerlukan perawatan sebelum diekstraksi ke dalam vektor fitur. Istilah matematika, data mentah ini ditunjukkan dalam rumus (1), (2), (3), (4) dan (5).

Sensor Accelerometer dan gyroscope

$D_{a}=\sum_{i=1}^{n}\left[\begin{array}{ccc}v_{x_{i}} & v_{y_{i}} & v_{z_{i}} \\ \vdots & \vdots & \vdots \\ v_{y_{n}} & v_{y_{n}} & v_{z_{n}}\end{array}\right]$

Sensor Gyroscope
$D_{g}=\sum_{i=1}^{n}\left[\begin{array}{ccc}v_{x_{i}} & v_{y_{i}} & v_{z_{i}} \\ \vdots & \vdots & \vdots \\ v_{x_{n}} & v_{y_{n}} & v_{z_{n}}\end{array}\right]$

Sensor Orientation

$D_{o}=\sum_{i=1}^{n}\left[\begin{array}{cccc}v_{x_{i}} & v_{y_{i}} & v_{z_{i}} & v_{w_{i}} \\ \vdots & \vdots & \vdots & \vdots \\ v_{x_{n}} & v_{y_{n}} & v_{z_{n}} & v_{w_{n}}\end{array}\right]$

Sensor Euler-orientation

$D_{e}=\sum_{i=1}^{n}\left[\begin{array}{ccc}v_{\text {roll }_{i}} & v_{\text {pitch }_{i}} & v_{\text {yaw }_{i}} \\ \vdots & \vdots & \vdots \\ v_{\text {roll }_{n}} & v_{\text {pitch }_{n}} & v_{\text {yaw }_{n}}\end{array}\right]$

Sensor EMG

$D_{m}=\sum_{i=1}^{n}\left[\begin{array}{cccc}v_{e m g 1_{i}} & v_{e m g 2_{i}} & \ldots & v_{e m g 8_{i}} \\ \vdots & \vdots & \vdots & \vdots \\ v_{e m g 1_{n}} & v_{e m g 2_{n}} & \ldots & v_{e m g 8_{n}}\end{array}\right]$

Dimana:

$D_{a} \quad=$ data dari sensor accelerometer

$D_{g} \quad=$ data dari sensor gyroscope

$D_{o} \quad=$ data dari sensor orientation

$D_{e} \quad=$ data dari sensor euler-orientation

$D_{m} \quad=$ data dari sensor EMG

$v \quad=$ nilai pengukuran

$n \quad=$ ukuran data

1) Metode Min-Max: data sensor tidak konsisten dengan skala, sehingga membutuhkan proses normalisasi. Penelitian ini menggunakan metode Min-Max untuk normalisasi data.

newdata $=\frac{1}{\max -\min } x($ data $-\min )$

dimana:

$\max =$ nilai maksimum dari $v$

$\min =$ nilai minimum dari $v$

Keuntungan dari metode ini adalah keseimbangan antara nilai data perbandingan. Tidak ada data yang dominan dibandingkan dengan data lain. Proses ini dilakukan karena data yang diperoleh EMG menghasilkan data pola 2 dimensi dengan selisih nilai data. Gambar 13 menunjukkan dua pola data yang berbeda. Pola 1 adalah sinyal ke posisi otot diam, dan pola 2 adalah sinyal ke posisi otot [24].

2) Metode Moment Invariant: Fitur ekstraksi dalam penelitian ini menggunakan momen invarian. Momen adalah nilai skalar yang menangkap fitur signifikan. Nilai ini memberikan karakteristik objek yang secara unik mewakili bentuk. Ide dasarnya adalah untuk menggambarkan objek dengan jumlah yang dapat diukur yang disebut invarian, tidak sensitif terhadap deformasi tertentu dan memberikan kekuatan yang cukup untuk 
mengenali objek termasuk kelas yang berbeda [25]. Proses selanjutnya adalah pembentukan fitur vektor dengan menghitung mean, median, standar deviasi, dan kemiringan pada setiap sumbu data sensor.

$$
\begin{gathered}
\bar{X}_{D_{(a, g, o, e, m)}}=\frac{\sum_{i=1}^{j} D_{(a, g, o, e, m)}}{n} \\
M e_{D_{(a, g, o, e, m)}}=\frac{(n+1)}{2} \\
S_{D_{(a, g, o, e, m)}}=\sqrt{\frac{\sum_{i=1}^{j}\left(v_{i}-\bar{X}\right)^{2}}{n-1}} \\
S_{k_{(a, g, o, e, m)}}=\sqrt{\frac{\sum_{i=1}^{j}\left(v_{i}-\bar{X}\right)^{3}}{n-1}}
\end{gathered}
$$

Dimana:

$\begin{array}{ll}n & =\text { ukuran data } \\ \bar{X}_{D_{(a, g, o, e, m)}} & =\text { mean untuk setiap data sensor } \\ M e_{D_{(a, g, o, e, m)}} & =\text { median untuk setiap data sensor } \\ S_{D_{(a, g, o, e, m)}} & =\text { standard deviation untuk setiap } \\ \text { data sensor } & \\ S_{k_{(a, g, o, e, m)}} & =\text { skewness untuk setiap data } \\ \text { sensor } & \end{array}$

Hasil perhitungan (7), (8), (9), (10) menghasilkan model data dengan 84-bins untuk isyarat tangan.

$$
\begin{aligned}
D M_{a} & =\left[\begin{array}{ccc}
\bar{X}_{x} & \bar{X}_{y} & \bar{X}_{z} \\
M e_{x} & M e_{y} & M e_{z} \\
S d_{x} & S d_{y} & S d_{z} \\
S k_{x} & S k_{y} & S k_{z}
\end{array}\right] \\
D M_{g} & =\left[\begin{array}{ccc}
\bar{X}_{x} & \bar{X}_{y} & \bar{X}_{z} \\
M e_{x} & M e_{y} & M e_{z} \\
S d_{x} & S d_{y} & S d_{z} \\
S k_{x} & S k_{y} & S k_{z}
\end{array}\right] \\
D M_{o} & =\left[\begin{array}{llll}
\bar{X}_{x} & \bar{X}_{y} & \bar{X}_{z} & \bar{X}_{w} \\
M e_{x} & M e_{y} & M e_{z} & M e_{w} \\
S d_{x} & S d_{y} & S d_{z} & S d_{w} \\
S k_{x} & S k_{y} & S k_{z} & S k_{w}
\end{array}\right] \\
D M_{e} & =\left[\begin{array}{llll}
\bar{X}_{\text {roll }} & \bar{X}_{\text {pitch }} & \bar{X}_{\text {yaw }} \\
M e_{\text {roll }} & M e_{\text {pitch }} & M e_{\text {yaw }} \\
S d_{\text {roll }} & S d_{\text {pitch }} & S d_{\text {yaw }} \\
S k_{\text {roll }} & S k_{\text {pitch }} & S k_{\text {yaw }}
\end{array}\right]
\end{aligned}
$$

$D M_{m}=\left[\begin{array}{cccc}\bar{X}_{e m g 1} & \bar{X}_{e m g 2} & \ldots & \bar{X}_{e m g 8} \\ M e_{e m g 1} & M e_{e m g 2} & \ldots & M e_{e m g 8} \\ S d_{e m g 1} & S d_{e m g 2} & \ldots & S d_{e m g 8} \\ S k_{e m g 1} & S k_{e m g 2} & \ldots & S k_{e m g 8}\end{array}\right](15)$

Langkah selanjutnya adalah mengukur apakah vektor fitur itu sudah mewakili gerakan tangan atau tidak. Perhitungan formula (16) dan (17) menunjukkan sensitivitas data pada keragaman isyarat tangan.

$R=\frac{\sum_{i}^{j}\left(D M_{(a, g, o, e, m)_{i}}-D M_{(a, g, o, e, m)_{i+1}}\right)}{n}$

Robust $=\left\{\begin{array}{lc}1 ;-1<R<+1 \\ 0 ; \quad \text { else }\end{array}\right.$

Dimana:

$$
\begin{array}{ll}
R & =\text { differential of data } \\
D M_{(a, g, o, e, m)} & =\text { fitur vektor }
\end{array}
$$

\section{HASIL DAN PEMBAHASAN}

A. Gerakan yang berbeda dengan posisi yang berbeda

Gambar 11 menunjukkan vektor fitur untuk semua sensor di setiap gerakan. Ada perbedaan antara pola gerakan dengan gerakan lain (g), (h), (i). Ini menunjukkan vektor fitur dapat mengidentifikasi gerakan yang berbeda dan kuat untuk posisi itu.

\section{B. Gerakan Berbeda dengan Posisi Yang Sama.}

Gambar 11 menunjukkan bahwa data (a), (b), (c), (d) memiliki pola yang sama, sedangkan data (e) menghasilkan pola yang tidak sama. Terbukti bahwa kesamaan tidak mempengaruhi arah pergerakan data (a), (b), (c) dan (d).

\section{Gerakan yang sama dengan posisi yang berbeda.}

Gambar 11 menunjukkan bahwa data (a), (c), (d) dan (e) menghasilkan pola yang sama, sedangkan data (b) memiliki pola yang sama tetapi interval yang berbeda. Ini menunjukkan fitur vektor dapat mengenali gerakan yang sama, walaupun posisi dan arahnya berbeda. 


\section{Keakuratan pengenalan gerakan}

Berdasarkan analisis, pengujian lebih lanjut untuk Menentukan kinerja dataset yang telah dibuat menggunakan algoritma metode jarak Euclidian. Pengujian dilakukan dengan menggunakan semua fitur yang menghasilkan akurasi data sensor sebesar $70 \%$.

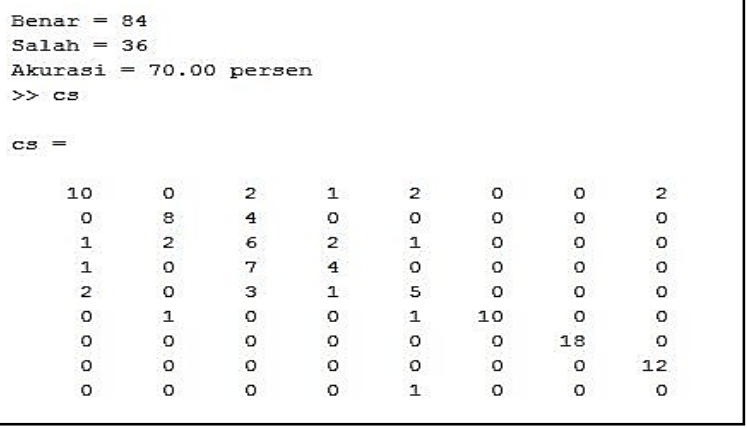

\begin{tabular}{rrrrrrrr}
10 & 0 & 2 & 1 & 2 & 0 & 0 & 2 \\
0 & 8 & 4 & 0 & 0 & 0 & 0 & 0 \\
1 & 2 & 6 & 2 & 1 & 0 & 0 & 0 \\
1 & 0 & 7 & 4 & 0 & 0 & 0 & 0 \\
2 & 0 & 3 & 1 & 5 & 0 & 0 & 0 \\
0 & 1 & 0 & 0 & 1 & 10 & 0 & 0 \\
0 & 0 & 0 & 0 & 0 & 0 & 18 & 0 \\
0 & 0 & 0 & 0 & 0 & 0 & 0 & 12 \\
0 & 0 & 0 & 0 & 1 & 0 & 0 & 0 \\
\hline
\end{tabular}

Gambar 12. Hasil akurasi dan validasi silang

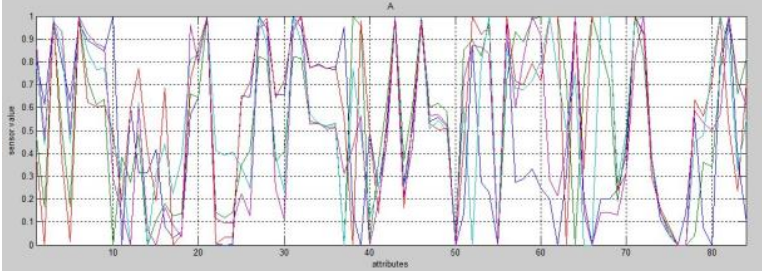

(a)

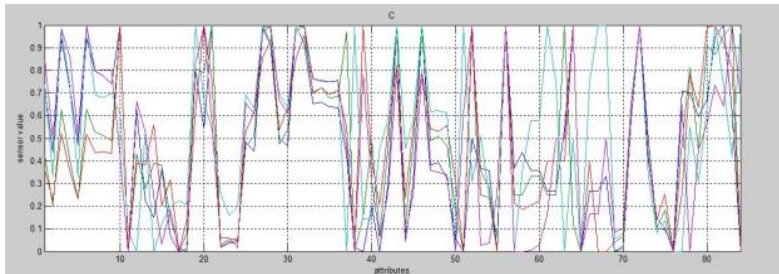

(c)

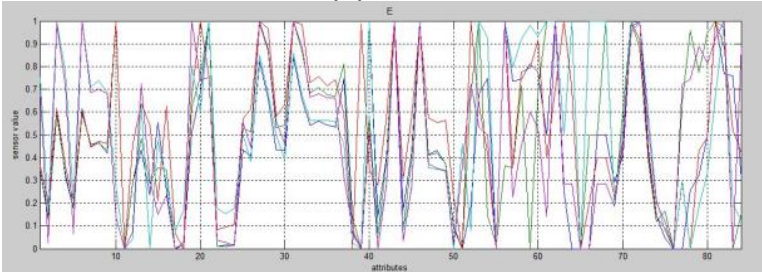

(e)

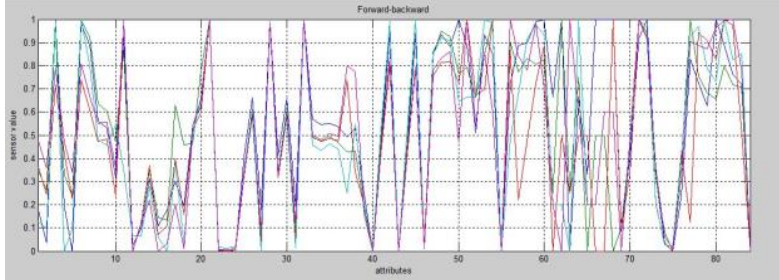

(g)

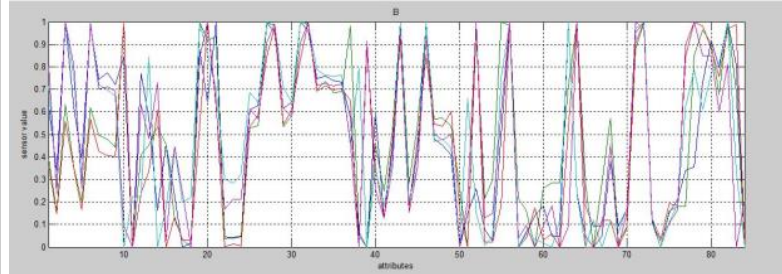

(b)

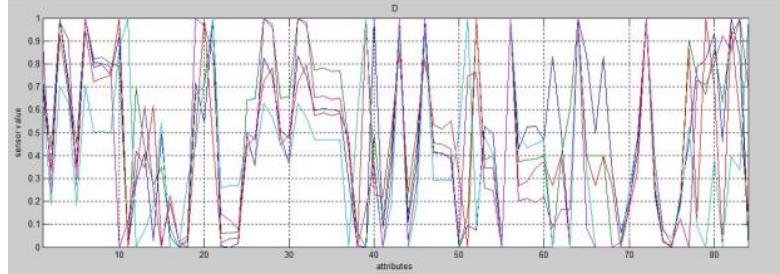

(d)

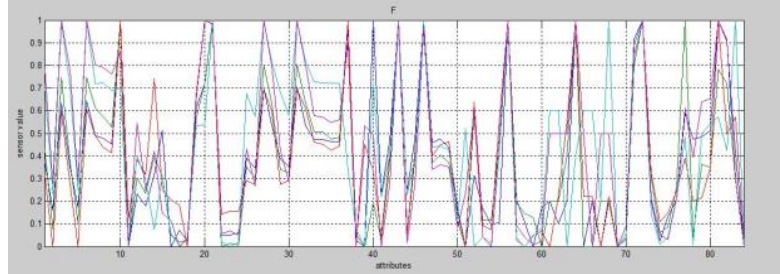

(f)

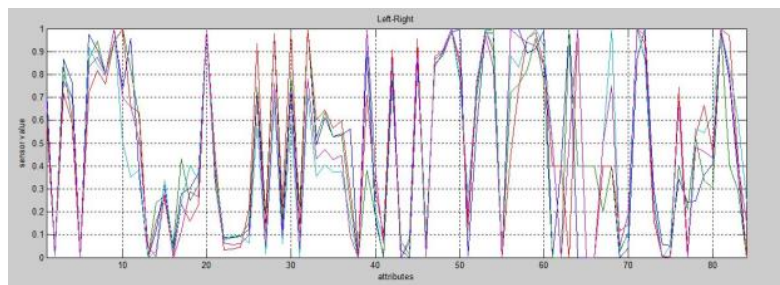

(h)

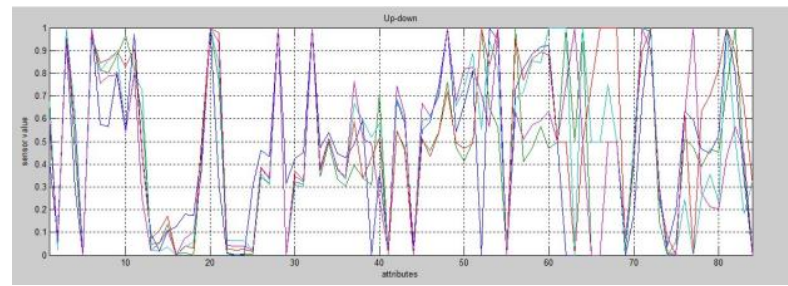

(i)

Gambar. 11.fitur untuk semua sensor pada setiap gestur, abjad A (a), abjad B (b), abjad C (c), abjad D (d), abjad E (e), abjad F (f), gerakan forward-backward (g), gerakan right-left (h), gerakan up-down (i). 
Hasil validasi silang pada gambar 12 . menunjukkan pengenalan gerakan yang dapat dikenali dengan benar oleh 84 dan salah 36 . Kemudian para peneliti mencoba mengukur akurasi jika hanya menggunakan sensor EMG, karena berdasarkan analisis grafik gambar 11. Sensor EMG memiliki efek yang cukup besar pada perbedaan dalam gerakan, tetapi hasil pengenalan gerakan menghasilkan akurasi $40,83 \%$.

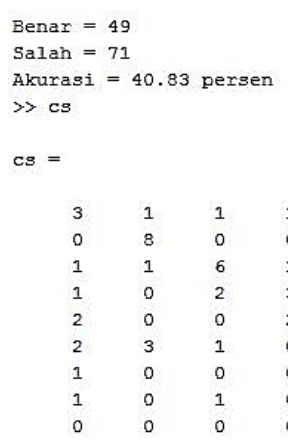

$\begin{array}{rrr}3 & 3 & 0 \\ 0 & 4 & 0 \\ 1 & 1 & 0 \\ 3 & 1 & 2 \\ 4 & 0 & 2 \\ 1 & 4 & 0 \\ 2 & 0 & 10 \\ 0 & 0 & 2 \\ 0 & 0 & 2\end{array}$

1
0
1
0
0
1
0
2
5

Gambar 13. Hasil akurasi sensor EMG dan validasi silang.

Gambar 13. menunjukkan bahwa hanya menggunakan sensor EMG menghasilkan akurasi hasil lebih buruk daripada menggunakan semua sensor. Hasil validasi silang dalam gambar 13 . menunjukkan pengenalan gerakan yang dapat dikenali dengan benar oleh 49 dan salah 71 .

Peneliti mencoba menguji lagi, tanpa menggunakan sensor accelerometer, menghasilkan akurasi $69,17 \%$. alasan peneliti menguji tanpa menggunakan sensor accelerometer untuk oleh grafik pada Gambar 11. diproduksi pola sensor accelerometer yang sama, sehingga para peneliti menyimpulkan untuk tidak menggunakan sensor ini. Namun, berdasarkan perhitungan menggunakan Euclidian distance gesture recognition menghasilkan akurasi yang lebih rendah daripada menggunakan semua fitur data sensor dalam gambar 12 .

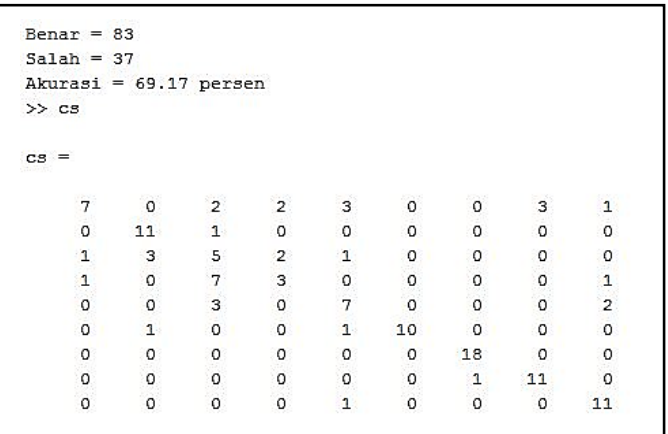

Gambar 14. Hasil akurasi tanpa menggunakan sensor accelerometer dan validasi silang.

Hasil validasi silang dalam gambar 14. menunjukkan pengenalan gerakan yang dapat dikenali dengan benar oleh angka 83 dan salah 37. Lalu, bagaimana jika sensor EMG tidak digunakan sebagai pengenalan gerakan? Jadi akurasi hasil pengukuran didapat sebesar $65 \%$.

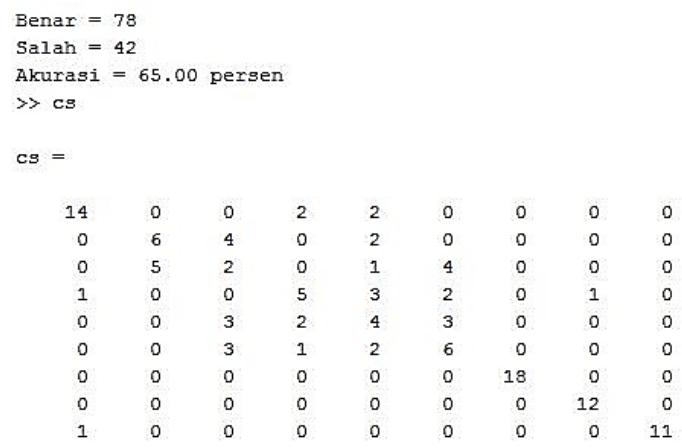

Gambar 15. Hasil akurasi tanpa menggunakan sensor EMG dan validasi silang

Hasil validasi silang dalam gambar 15 . menunjukkan pengenalan gerakan yang dapat dikenali dengan benar oleh 78 dan salah 42 .

\section{SIMPULAN DAN SARAN}

Berdasarkan metode ekstraksi fitur yang peneliti usulkan untuk variasi eksperimen yang berfokus pada jenis gerakan tangan apa yang statis dan dinamis. Dapat disimpulkan bahwa gerakan perbedaan yang dilakukan gerakan statis dan dinamis pasti akan dikenali dengan benar. Dengan menggunakan semua sensor pada alat MYO adalah accelerometer, gyroscope, orientasi, orientasi-Euler, dan EMG akan dihasilkan akurasi yang lebih baik daripada hanya menggunakan beberapa sensor yang ada pada MYO dengan akurasi hasil 70\%.

Ini membuktikan bahwa walaupun hasil analisis grafik pola accelerometer sensor tidak akan digunakan untuk membantu dalam pengantar, tetapi setelah pengujian menunjukkan keakuratan hasil akan lebih bagus jika semua sensor pada MYO digunakan.

Untuk penelitian lebih lanjut, metode ini akan dikembangkan dengan gerakan lain untuk pengenalan gerakan tangan sesuai 
dengan kamus bahasa isyarat dan akan menguji keakuratan pengenalan gerakan menggunakan metode klasifikasi lain untuk hasil terbaik

\section{UCAPAN TERIMA KASIH}

Peneliti mengucapkan terima kasih kepada semua pihak yang telah mendukung dalam menyelesaikan penelitian ini dalam bentuk waktu, motivasi, dan juga pengetahuan.

\section{REFERENSI}

[1] M. T. Wolf, C. Assad, A. Stoica, K. You, H. Jethani, M. T. Vernacchia, J. Fromm, and Y. Iwashita, "Decoding static and dynamic arm and hand gestures from the JPL BioSleeve," IEEE Aerosp. Conf. Proc., 2013.

[2] F. Ramirez-Garibay, C. M. Olivarria, A. F. E. Aguilera, and J. C. Huegel, "MyVox-Device for the communication between people: blind, deaf, deaf-blind and unimpaired," IEEE Glob. Humanit. Technol. Conf. (GHTC 2014), pp. 506-509, 2014.

[3] S. Mitra, S. Member, T. Acharya, and S. Member, "Gesture Recognition: A Survey," IEEE, vol. 37, no. 3, pp. 311324, 2007.

[4] L. Chen, F. Wang, H. Deng, and K. Ji, "A Survey on Hand Gesture Recognition," 2013 Int. Conf. Comput. Sci. Appl., pp. 313-316, 2013.

[5] Z. Yang and S. Narayanan, "Modeling Dynamics of Expressive Body Gestures In Dyadic Interactions," IEEE Trans. Affect. Comput., vol. XX, no. XX, pp. 11, 2016.

[6] S. Ongkittikul, S. Worrall, and A. Kondoz, "Two hand tracking using colour statistical model with the K-means embedded particle filter for hand gesture recognition," 7th Comput. Inf. Syst. Ind. Manag. Appl. CISIM 2008, pp. 201-206, 2008.

[7] V. Bhame, R. Sreemathy, and H. Dhumal, "Vision based hand gesture recognition using eccentric approach for human computer interaction," 2014 Int. Conf. Adv. Comput. Commun. Informatics, pp. 949-953, 2014.
[8] S. S. Ge, Y. Yang, and T. H. Lee, "Hand Gesture Recognition and Tracking based on Distributed Locally Linear Embedding," IEEE, no. ii, 2006.

[9] S. Khare, "Finger gesture and pattern recognition based device security system," 2015 Int. Conf. Signal Process. Commun. ICSC 2015, pp. 443-447, 2015.

[10] "Multi-Feature Criteria with Fuzzy Logic Pattern Recognition for Hand Gesture Classification," IEEE 58th Int. Midwest Symp. Circuits Syst., pp. 1-4, 2015.

[11] M. Vanco, I. Minarik, and G. Rozinaj, "Evaluation of static hand gesture algorithms," 21st Int. Conf. Syst. Signals Image Process., no. May, pp. 83-86, 2014.

[12] Y. Liu, Y. Yang, L. Wang, J. Xu, H. Qi, X. Zhao, P. Zhou, L. Zhang, B. Wan, D. Ming, D. Guo, B. Shi, and J. Wang, "Image processing and recognition of multiple static hand gestures for humancomputer interaction," Proc. - 2013 7th Int. Conf. Image Graph. ICIG 2013, pp. 465-470, 2013.

[13] V. et al Elamaran, "Image Processing Algorithms for Gesture Recognition using MATLAB," 2014 IEEE Int. Conf. Adv. Commun. Control Comput. Technol., no. 978, pp. 0-1, 2014.

[14] T. Verma and S. M. Kataria, "Hand Gesture Recognition Techniques: a Review," Int. Res. J. Eng. Technol., vol. 03, no. 04, pp. 190-193, 2016.

[15] M. Sathiyanarayanan and T. Mulling, "Map Navigation Using Hand Gesture Recognition: A Case Study Using MYO Connector on Apple Maps," Procedia Comput. Sci., vol. 58, pp. 50-57, 2015.

[16] T. Mulling and M. Sathiyanarayanan, "Characteristics of Hand Gesture Navigation: a case study using a wearable device (MYO)," in Proceedings of the 2015 British HCI Conference on British HCI '15, 2015, pp. 283-284.

[17] A. F. Ruiz-olaya, M. Callejas-cuervo, and A. M. Perez, "EMG-based Pattern Recognition with Kinematics Information for Hand Gesture Recognition," Signal Process. Images Comput. Vis. (STSIVA), 2015 20th Symp., pp. 1-4, 2015. 
[18] M. Sathiyanarayanan and S. Rajan, "MYO Armband for Physiotherapy Healthcare : A Case Study Using Gesture Recognition Application," IEEE, pp. 1-6, 2016.

[19] Z. Arief, I. A. Sulistijono, and R. A. Ardiansyah, "Comparison of five time series EMG features extractions using Myo Armband," 2015 Int. Electron. Symp., pp. 11-14, 2015.

[20] Wahyudi, A. Susanto, W. Widada, and S. P. Hadi, "Inertial Measurement Unit using multigain accelerometer sensor and gyroscope sensor," Proc. 2011 Int. Conf. Electr. Eng. Informatics, ICEEI 2011, no. July, pp. 4-8, 2011.

[21] T. Harada, H. Uchino, T. Mori, and T. Sato, "Portable orientation estimation device based on accelerometers, magnetometers and gyroscope sensors for sensor network," IEEE Int. Conf. Multisens. Fusion Integr. Intell. Syst., vol. 2003-Janua, pp. 191-196, 2003.

[22] E. Fresk and G. Nikolakopoulos, "Full Quaternion Based Attitude Control for a Quadrotor," Eur. Control Conf., pp. 3864-3869, 2013.

[23] M. Kumar, D. P. Garg, and R. A. Zachery, "A method for judicious fusion of inconsistent multiple sensor data," IEEE Sens. J., vol. 7, no. 5, pp. 723-733, 2007.

[24] Y. Makino, S. Ogawa, and H. Shinoda, "EMG sensor integration based on TwoDimensional Communication," Proc. INSS 2008 - 5th Int. Conf. Networked Sens. Syst., pp. 140-147, 2008.

[25] J. Flusser, B. Zitova, and T. Suk, Moments and Moment Invariants in Pattern Recognition; Kapitel 6, First Edit. Prague, Cezh Republic: WILEY, 2010. 